\title{
Modelling spider monkeys Ateles spp. Gray, 1825: ecological responses and conservation implications to increased elevation
}

\author{
Sam Shanee \\ Neotropical Primate Conservation, 65 Whaddon Road, Cheltenham, Gloucestershire GL52 5NE, UK \\ Email: samshanee@gmail.com
}

Date of publication (online): 26 September 2009 Date of publication (print): 26 September 2009 ISSN $0974-7907$ (online) | $0974-7893$ (print)

Editor: Cecília Kierulff

\section{Manuscript details:}

Ms \# 02189

Received 28 April 2009

Final received 11 September 2008

Finally accepted 12 September 2009

Citation: Shanee, S. (2009). Modelling spide monkeys Ateles spp. Gray, 1825: ecological responses and conservation implications to increased elevation. Journal of Threatened Taxa 1(9): 450-456.

Copyright: (C) Sam Shanee 2009. Creative Commons Attribution 3.0 Unported License. JoTT allows unrestricted use of this article in any medium for non-profit purposes, reproduction and distribution by providing adequate credit to the authors and the source of publication.

Author Details: Sam Shanee has worked in primate conservation and reintroduction for the past eight years in South America and Asia. He studied primate conservation at Oxford Brookes University and in 2007 co-founded the UK based NGO Neotropical Primate Conservation. He currently works in Peru researching the Yellow-tailed Woolly Monkey.

Acknowledgements: I wish to thank Noga Shanee, Dr. Mika Peck, Marcelo FernandezBolanos, Dr. Alejandro Estrada, Dr. Thomas Defler, Dr. Antony DiFiore, Ana Mariscal, Martin Stanley, and Jose DeCoux for their help in researching and preparing this study and their enlightening inputs although not all of it could be accommodated here.
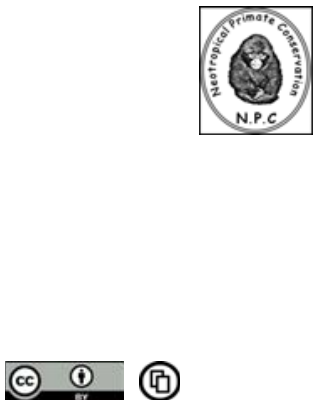

OPEN AGGESS | FREE DOWNLOAD
Abstract: Spider monkeys (Ateles spp.) are among the most widely-distributed and endangered neotropical primate genera. Throughout their distribution expanding human populations and associated demands for land are causing widespread deforestation, especially in low-lying areas where many populations of spider monkeys are being pushed to high elevation sites with sub-optimal conditions. In this paper ecological data from a wide range of sources has been collected and examined to try to better understand and predict spider monkey ecological responses to high elevation areas with lower environmental carrying capacities. Results show a significant reduction in group and foraging party sizes with increased elevation. A general reduction in density is also noted with increasing elevation, while home range sizes remain static. It is recommended that these observations be taken into account when planning conservation actions and new protected areas, and further implications are also discussed.

Keywords: Altitude, Ateles, carrying capacity, conservation, ecology, elevation, neotropics.

\section{INTRODUCTION}

The genus Ateles Gray, 1825, spider monkeys, is one of the most widely distributed of neotropical primate groups (Collins 2008). They are found from southern Mexico south to Bolivia and east through Venezuela and the Guianas to the Atlantic coast of Brazil (Groves 2001). This genus is also one of the most threatened, with two species: the Black-headed Spider Monkey (A. fusciceps) and the Brown Spider Monkey ( $A$. hybridus) having featured on the IUCN's list of the top 25 most endangered primate species (Primate Specialist Group 2009). The IUCN Primate Specialist Group currently recognizes seven distinct species of Ateles; the monotypic A. belzebuth; $A$. chamek; $A$. fusciceps; $A$. geoffroyi; $A$. marginatus; $A$. paniscus; and $A$. hybridus (IUCN 2009). Both $A$. fusciceps and $A$. hybridus are listed as Critically Endangered (IUCN 2009). Although more recent studies dispute this taxonomy (Collins \& Dubach 2000; Collins 2008), for the purposes of this paper I prefer to follow the taxonomy currently accepted by the IUCN.

The main threats to this genus are from anthropogenic hunting pressure and habitat loss (Ramos-Fernandez \& Ayala-Orozoco 2003; DiFiore 2004; Wallace 2008). Spider monkeys are the largest-bodied of the neotropical primate groups (Di Fiore \& Campbell 2007) and thus they are commonly hunted for food (Peres 2000; Thoisey et al. 2005; Ramos-Fernandez \& Ayala-Orozoco 2003; Wallace 2008), which has led to their extirpation in large areas of their former distribution. Low reproductive rates, long interbirth intervals, high infant mortality, low population densities and a low intrinsic rate of natural increase (DiFiore \& Campbell 2007) means that they are particularly vulnerable to anthropogenic hunting pressure. Spider monkeys are highly frugivorous primary forest specialists (DiFiore et al. 2008) that do not adapt well to degraded and secondary forest areas (Defler 2004), making them the most susceptible of new world primates to anthropogenic pressures (DiFiore \& Campbell 2007). The preferred habitat of spider monkeys is <800m (Collins 2008), although many studies document their presence at higher elevations.

The fission-fusion social structure of spider monkey groups, similar to that of chimpanzees (Symington 1988, 1990), enables large groups to successfully forage for scattered resources by separating into smaller foraging parties of dynamic structure (Symington 1988; Wallace 2007). Even so, such large groups also require large home ranges; Pozo (2001) reports a home range size of 469 ha for a single group of $A$. belzebuth in Ecuador. This may be a factor in their reduced ability to survive in small forest patches and areas of secondary and degraded forest.

Five of the seven species are found at least partially within 'Biodiversity Hotspots' (Myers et al. 2000) with A. fusciceps and A. geoffroyi endemic to the Choco/Darien/ 
western Ecuador and Mesoamerica hotspots, respectively. Among other things these hotspots are characterized by the high level of threats they face. Tirrira (2004) estimates that $80 \%$ of $A$. fusciceps' habitat has already been lost. Similarly, only 20\% of the Mesoamerican hotspot remains (Meyers et al. 2000). As demand for land increases along with increasing human populations (Estrada 2006), large scale clearance of forest cover has occurred in all neotropical ecosystems. Land clearance usually occurs first in more easily accessible lowland areas (Estrada \& Coates-Estrada 1996) that are the preferred habitat of spider monkeys (Collins 2008). In some areas, notably in western Ecuador (Sam Shanee pers. obs.) and Veracruz in southern Mexico (Estrada \& Coates-Estrada 1996), this large scale clearance of forest in low lying areas effectively forces the migration of species to areas of higher elevations with suboptimal conditions.

Many studies have documented changes in forest community structure and primary production levels with increasing elevation (Lawes 1992; Smith \& Killeen 1998; Costa 2006; Bendix et al. 2008; Shanee \& Peck 2008). These changes occur due to a number of interrelated factors including: temperature reduction, changes in soil $\mathrm{pH}$ and precipitation levels and increased exposure to solar radiation (Marshall et al. 2005). Generally, as elevation increases primary production levels decrease, reducing resource availability to consumers (Durham 1975; Caldecott 1980; Marshall et al. 2005). The spider monkeys $A$. belzebuth, A. Chamek, A. fusciceps, A. geoffroyi, A. hybridus and $A$. paniscus all have distributions which include high elevation sites.

Several studies have recorded changes in primate ecology at high elevations. Gesie et al. (2004) found that the frequency of primate species in the Itatiaia Nation Park, Brazil peaked at $1000 \mathrm{~m}$. The only representative of the sub-family Atelinae, Brachyteles arachnoids or southern Muriqui, was not present above $\sim 1300 \mathrm{~m}$. Marshall et al. (2005) reported lower abundance of red colobus monkeys (Procolobus gordonorum) at higher elevations in Uganda, and Caldecott (1980) reported similar trends for gibbons (Hylobatidae) in Malaysia. Most interestingly in relation to this study, Durham (1975) reported progressively smaller groups of $A$. chamek (although referred to as $A$. paniscus by Durham) at increasing elevations, and Peck (2008) reported lower abundance of $A$. fusciceps with increasing elevation in Ecuador. In all cases these localized changes in the species' population ecology were attributed to changes in habitat and climatic conditions at the higher elevation sites.

In this study I have made a meta analysis of changes in spider monkey population ecology in relation to increasing elevation. Data from a wide range of sources has been used to obtain a fuller picture of changes in group sizes, foraging party size, home-range sizes and population densities. I have also tried to examine how these variables are related to each other and identify the major causes. It is felt that greater understanding of the effects of elevation will aid future conservation planning.

\section{Materials And Methods}

Data used in this study include all areas of spider monkeys distribution throughout most of tropical South and Central America. Habitat types include: moist tropical, deciduous lowland rainforest and premontane and montane cloud forest
(DiFiore \& Campbell 2007) as well as a number of climatic zones.

Mountain ranges within the distribution of the various species include: the eastern slopes of the Andes in Bolivia, Colombia Ecuador and Peru where A. Belzebuth and A. Chamek are present at $1950 \mathrm{~m}$ (Sam Shanee pers. obs.) and $1432 \mathrm{~m}$ (McFarland-Symington 1986) respectively; the western slopes of the Andes where $A$. fusciceps is present at $>1800 \mathrm{~m}$ (GavilanezEndara 2006); the Sierra Madre de Oaxaca in Mexico where $A$. geoffroyi is present up to $1398 \mathrm{~m}$ (Briones-Salas et al. 2006); the Venezuelan coastal range where $A$. hybridus is cited to be present at $1100 m$ (Cordero-Rodriguez \& Biord 2001) and the Pakaraima and Roraima mountains of the Guianan shield where $A$.paniscus is cited to be present at $>600 \mathrm{~m}$ (van Roosmalen 1985). Elevations given here only included sites where previous studies have taken place, all mountain ranges include areas of higher elevations where it is likely that spider monkeys are also present. No previous studies have documented the presence of $A$. marginatus at high elevations, thus this species is not included in this analysis. Only data for species where studies have included the relevant results at high elevation sites were used for the respective analyses which lead to the exclusion of $A$. belzebuth from the analyses, although this species has been observed at $1750 \mathrm{~m}$ (Sam Shanee pers. obs.).

Elevation data presented a problem, as many of the studies did not include this in their published reports. Where elevation data were missing I searched the literature for studies made at the same sites, preferably by the same authors, to ensure accuracy. Failing this, elevation data on specific study sites and locations were requested from third parties currently active at these locations.

In addition to elevation, data collected included actual or mean spider monkey group size, foraging party size, individual and group density, home range size and daily path length.

Certain assumptions were made regarding the data used in the analysis (Dunbar 2002). Assumptions made for this analysis were necessary as data specific to differences in population ecology of spider monkeys (particularly concerning elevation) are scarce and distributed widely between species, geographically and on a temporal scale. For these reason the following assumptions were necessary:

- Spider monkey responses to high elevations are similar between species, sub-species and populations.

- Data gathered from the literature represents the true, natural, state of spider monkey populations at a given site.

- Anthropogenic factors have remained constant for the time period between studies.

\section{RESULtS}

Data were collected from a total of 38 published studies and one unpublished, covering all species of Ateles. This included studies at 33 sites in 11 countries throughout the genera's distribution (Table 1 ). Elevations ranged from sea level $(+/-0 \mathrm{~m})$ to $1800 \mathrm{~m}$, a mean group size of $16.2(\min 3.3$, $\max 45)$, mean foraging party size of $4.7(\min 2.5, \max 6.85)$, mean density of 0.21 individuals per ha ( $\min 0.01, \max 0.66$ ), mean home range of 227 ha $(\min 108, \max 316$ ) and mean daily path length of $2236 \mathrm{~m}$ ( $\min 1977$, $\max 2400$ ) were found.

Data were entered into SPSS V16.0 for Windows for statistical analysis. All data sets showed normal (Shapiro-Wilk, 
Table 1. Spider monkey group structure and elevations, studies used in this analysis

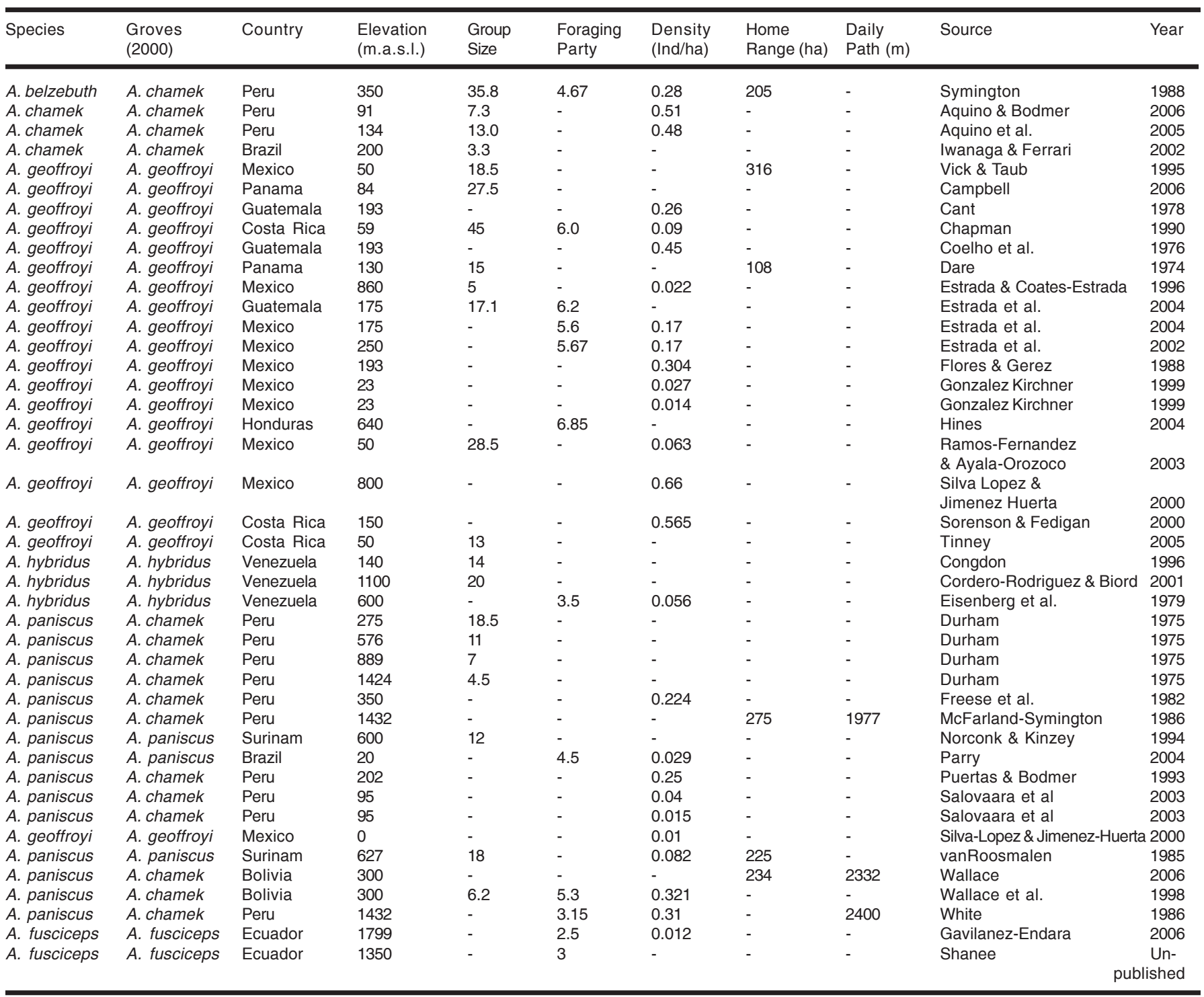

$>0.05$ ) distributions except spider monkey densities (ShapiroWilk, <0.05), which were log (Base-10 Logarithm) transformed to give a normal distribution.

Preliminary analyses were made on $A$. geoffroyi, as this species presented the largest individual data set (18 studies). Linear regression scatter plots suggested relationships between changes in elevation and density, group size and foraging party size. Non-parametric correlation analyses, spearmans rho, showed a significant relationship between changes in elevation and density ( $\mathrm{r} 0.724$, df $11, \mathrm{p}<0.01$ ). No significant relationship was found between elevation and group size $(\mathrm{r}$ 0.439 , df $7, \mathrm{p}>0.05$ ) or foraging party size ( $\mathrm{r} 0.359$, df $4, \mathrm{p}$ $>0.05)$.

Linear regression scatter plot graphs with 95\% mean prediction intervals were produced using combined data for the five species to be included in the final analyses; $A$. chamek, A. fusciceps, A. geoffroyi, A. hybridus and A.paniscus. Spider monkey densities, group sizes and foraging party sizes can all be seen to decrease with increasing elevation (Figs. 1, 2 \& 3), whereas home range size was seen to be fairly constant with increasing elevation. Non-parametric statistical analyses, Spearmans rho, showed significant correlations between changes in spider monkey group size ( $\mathrm{r} 0.548$, df $16, \mathrm{p}<0.01)$ and foraging party size ( $\mathrm{r} 0.594$, df $7, \mathrm{p}<0.05$ ) with increasing elevation. Elevation did not have a significant effect on spider monkey home range size ( $\mathrm{r} 0.479$, df $4, \mathrm{p}>0.05$ ) or density ( 0.068 , df 23, p $>0.05)$. Tests showed no significant correlation between differences in group size and home range size ( $\mathrm{r} 0.30$, df $2, \mathrm{p}$ $>0.05$ ).

Regression curve estimation showed a decrease in average group size of approximately one individual for $100 \mathrm{~m}$ increase in elevation, a decrease in density of 0.002 individuals per hectare was also shown for $100 \mathrm{~m}$ increase in elevation. By adapting the results of the regression analysis we get the predictive equation for the density of spider monkey species found at high elevations:

$$
\mathrm{Dp}=\mathrm{Dk}+(0.002(\mathrm{EDk}-\mathrm{EDp})
$$

Where Dp is the predicted density at elevation $x$, Dk is the known density at elevation $y$, EDk is elevation $y$ and EDp is elevation $x$, with elevation measured in meters. A similar 


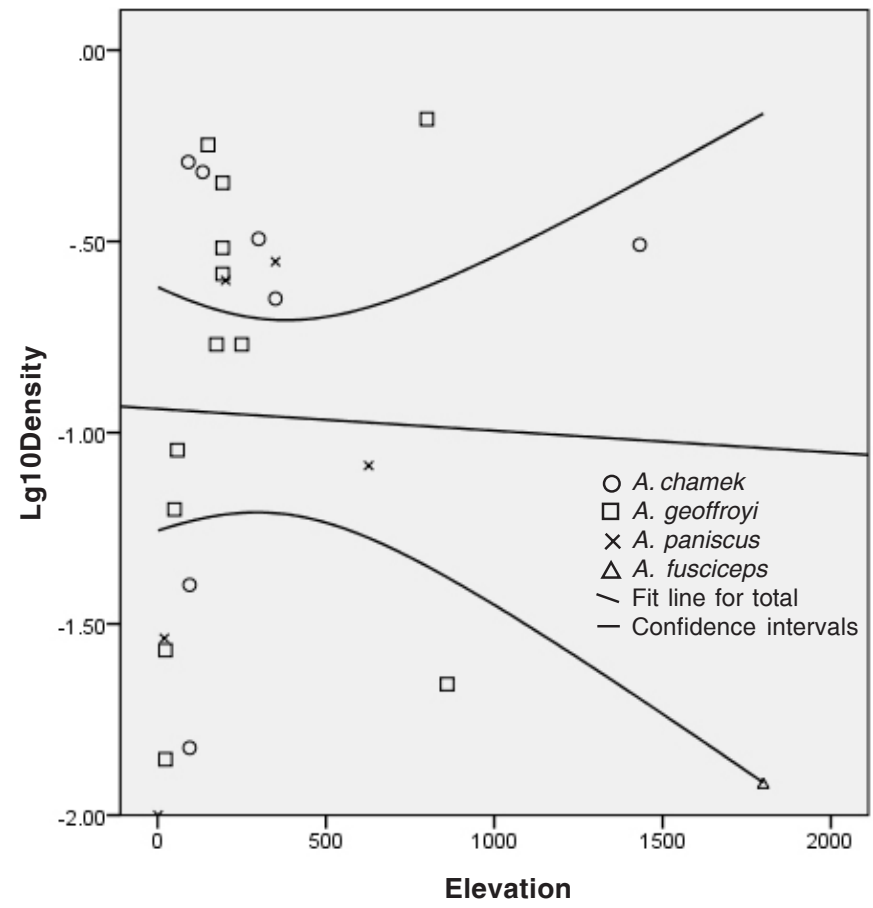

Figure 1. Regression of log spider monkey density against elevation

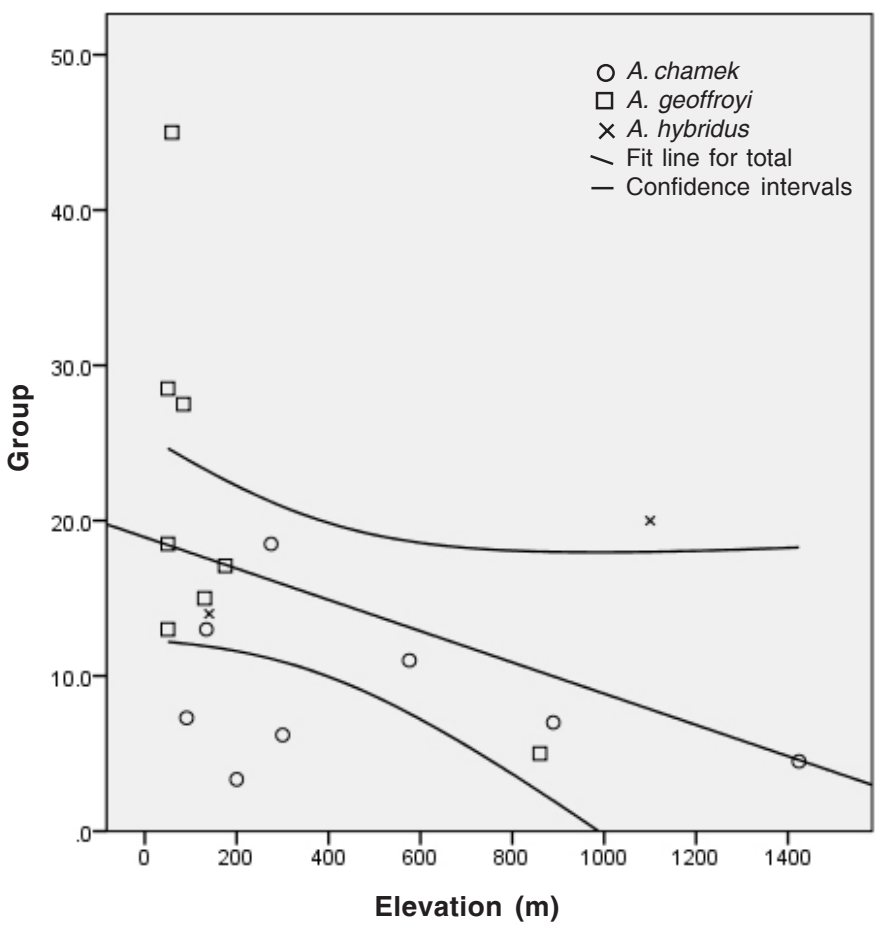

Figure 2. Regression of spider monkey group size against elevation. predictive equation is produced for group sizes of spider monkey species found at high elevation sites:

$$
\mathrm{Gp}=\mathrm{Gk}+(0.01(\mathrm{EGk}-\mathrm{EGp})
$$

Where $\mathrm{Gp}$ is the predicted group size at elevation $x$, Gk is the known group size at elevation $y$, EGk is elevation $y$ and EGp is elevation $x$, with elevation measured in meters.

\section{Discussion \& Conclusions}

With decreased food quantity and quality at higher elevations (Durham 1975; Caldecott 1980; Marshall et al. 2005), home range size would be expected to increase if group sizes and densities remained static, due to the extra area needed for successful foraging. No correlation was found between elevation and home range area suggesting the most efficient way of maximizing food intake per animal per unit area is through decreasing group size and density (McFarlandSymington 1986; Wrangham et al. 1993); which is supported by the significant correlation found between decreases in group size and increased elevation. This logically extends to foraging party size, as it is in these units that spider monkeys need to find sufficient food per day/per unit area, which is backed up by the significant correlation found between decreases in foraging party size with increases in elevation. This suggests that there is an optimum range size (Cowlishaw \& Dunbar 2000) found with a balance between energy expenditure and intake (Wrangham et al. 1993) as well as competition for resources and predator avoidance. This should be especially important with the increased energetic costs of high elevation living (Marshall et al. 2005). Increases in range sizes with increasing group sizes would most likely be seen where populations are not primarily limited by environmental factors (Cowlishaw \& Dunbar 2000; Gillespie \& Chapman 2001).

When planning protected area systems altitudinal effects on environmental carrying capacity need to be considered. Minimum viable population sizes have been estimated to be between 500-1000 (Franklin \& Frankham 1998; Lynch \& Lande 1998). Results here suggest that reserves designed to protect viable populations of Ateles would need to encompass larger areas depending on the elevation above sea level of the area. Recent studies (Peck 2008) have documented decreases in the occurrence of $A$. fusciceps with increased elevation in the Choco forests of Ecuador. In the same area the occurrence and fruit production of Ficus spp. trees, one of the most important food resource for spider monkeys (DiFiore et al. 2008), have been shown to significantly decrease with elevation (Shanee \& Peck 2008), thus increasing the importance of preserving the preferred, lowland, habitat of spider monkeys (Collins 2008).

Results suggest that spider monkeys tend to live in smaller groups and at lower densities in higher elevation sites, whilst maintaining similar size home ranges. This could lead to greater risk of extinction in populations forced to live in isolated forest fragments at higher elevations, as well as in populations naturally found at high elevations. Although the decrease in density predicted here is relatively small, 0.02 individuals/ $100 \mathrm{~m}$ increase in elevation, the decrease predicted in group size is much more pronounced, 1 individual/100m increase in elevation. This could cause pronounced differences in the viability of populations. For example, with an average spider 


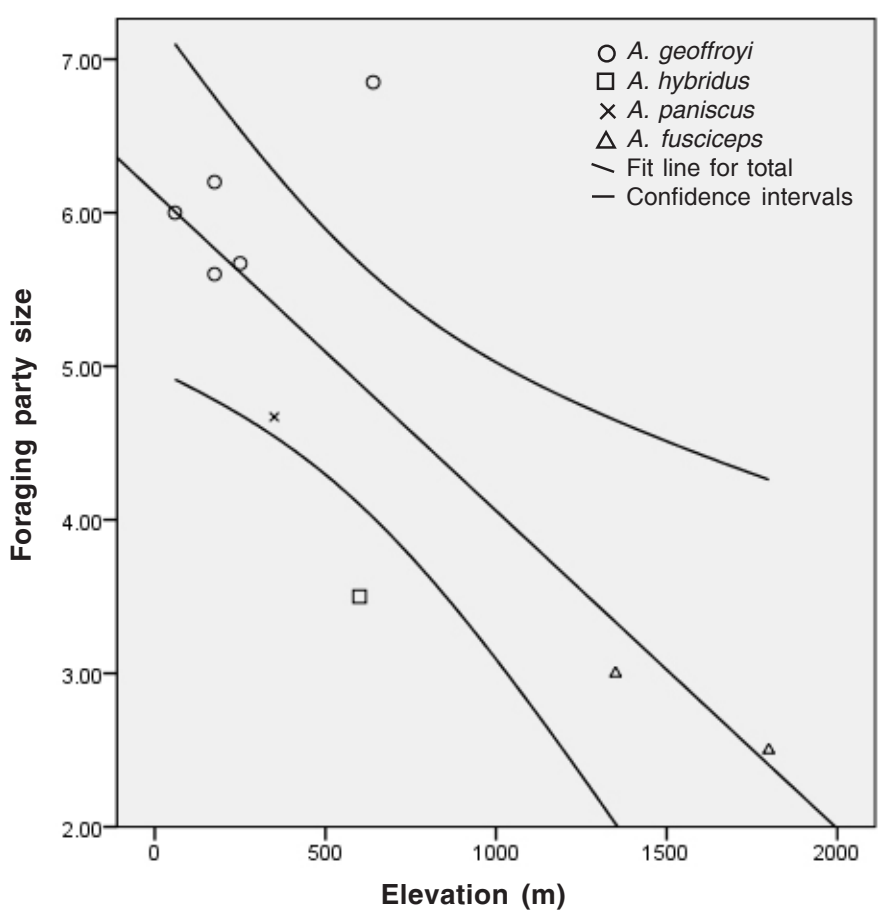

Figure 3. Regression of spider monkey foraging party size against elevation.

monkey group size below 100 m of 20 , such a decrease would lead to a $50 \%$ drop in group size at $1000 \mathrm{~m}$. This drop is caused by the differences in habitat and primary production levels creating suboptimal conditions in relation to spider monkey evolutionary and behavioural adaptations (Estrada \& CoatesEstrada 1996). This is further complicated by interspecific competition for resources with species which are better adapted to the conditions prevalent in high elevation sites.

Relatively few investigations have focused on primate ecological responses to increased elevation. However, several studies do exist (for example: Henzi et al. 1990; Kumara \& Singh 2004). Generally findings have shown a decrease in individual and group densities at higher elevation sites in comparison to lower elevations (Caldecott 1980; Marshall et al. 2005) similar to those predicted in this study. Many more studies exist on changes to animal ecology in relation to elevational gradients, including frugivorous neotropical bats (Giannini 1999) and Birds (Loiselle \& Blake 1991), as well as on forest structure in general (Liberman et al. 1996) which show similar changes due to increases and decreases in elevation. The analyses presented here were severely limited by a lack of data from high elevation sites. However, findings, combined with results from other studies, show the need for the effects of increased elevation on carrying capacity and group ecology to be taken into account when planning conservation measures such as new protected areas. I recommend more field studies be made to investigate the causes and effects of these changes in detail especially in light of current and predicted climate change which is causing marked shifts in species altitudinal distributions as well as vegetation types (Wilson et al. 2005; Lenoir et al. 2008) which pose interesting questions as to where species will find suitable habitat in the future.

\section{References}

Aquino, R. \& R.E. Bodmer (2006). Distribution and abundance of Ateles belzebuth E Geoffroy and Ateles chamek Humboldt (Cebidae: Primates) in the Pacaya Samiria National Reserve, Peru. Revista Peruana de Biologia 13: 103-106.

Aquino, R., J. Alvarez \& A. Mulanovich (2005). Diversity and conservation status of primates in the Sierras de Contamana, Peruvian Amazonia. Revista Peruana de Biologia. 12: 427-424.

Bendix, J., R. Rollenbeck, M. Richter, P. Fabian \& P. Emck (2008). Climate pp. 63-74. In: Beck, E., J. Bendix, I. Kottke, F. Makeschin \& R. Mosandl (eds.). Gradients in a Tropical Mountain Ecosystem of Ecuador Springer-Verlag, Berlin, xxiv+526pp.

Briones-Salas, M., M.D. Luna-Krauletz, A. Marín-Sánchez \& J. Servín (2006). Noteworthy records of two species of mammals in the Sierra Madre de Oaxaca, Mexico. Revista Mexicana de Biodiversidad. 77: 309-310

Caldecott, J.O. (1980). Habitat quality and populations of two sympatric Gibbons (Hylobatidae) on a Mountain in Malaya. Folia Primatologica. 33: 291-309.

Campbell, C.J. (2006). Lethal intragroup aggression by adult male spider monkeys (Ateles geoffroyi). American Journal of Primatology. 68: 11971201.

Cant, J.G. (1978). Population survey of the spider monkey Ateles geoffroyi at Tikal, Guatemala. Primates. 19: 525-535.

Chapman, C.A. (1990). Ecological constraints on group size in three species of neotropical primate. Folia Primatologica. 55: 1-9.

Coelho Jr, A.M., L. Coelho, C. Bramblett, S. Bramblett \& L.B. Quick, (1976). Ecology, population characteristics and sympatric association in primates: A socio-bioenergetic analysis of howler and spider monkeys in Tikal, Guatemala. Yearbook of Physical Anthropology. 20: $96-135$.

Collins, A.C. (2008). The taxonomic status of spider monkeys in the 21 st Century, pp. 50-80 In: Campbell, C.J. (ed.). Spider Monkeys: Behavior, Ecology and Evolution of the Genus Ateles. Cambridge University Press, Cambridge, $\mathrm{x}+420 \mathrm{pp}$

Collins, A.C. \& J. Dubach (2000). Phylogenetic relationships of spider monkeys (Ateles) based on Mitochondrial DNA variation. International Journal of Primatology. 21:421-444.

Congdon, E.R. (1996). A preliminary study of distribution habitat use and activity patterns of primates within CAPARO FORESTRT RESERVE, Venuzela. Report to PROFAUNA, MARNR, Caracas.

Cordero-Rodriguez, G.A. \& F.J. Biord (2001). Distribution and conservation of the spider monkey (Ateles hybridus) in the coastal range of northern Venezuela. Neotropical Primates. 9: 9-11.

Costa, F.R.C. (2006). Mesoscale gradients of herb richness and abundance in Central Amazonia. Biotropica. 38: 711-717.

Cowlishaw, D. \& R. Dunbar (2000). Primate Conservation Biology. The University of Chicago Press. London, xi+498pp

Dare, R. (1974). Food-sharing in free-ranging Ateles geoffroyi (red spider monkeys). Laboratory Primate Newsletter 13: 19-21.

Deflr, T.R. (2004). Primates of Colombia. Conservation International, Bogota. 550pp

Di Fiore, A. (2004). Primate Conservation. McGraw Hill Yearbook of Science and Technology. McGraw Hill, 425pp.

Di Fiore, A. \& C.J. Campbell (2007). The Atelines: variation in ecology, behavior, and social organization. pp. 155-185 In: Cmapbell C.J., A. Fuentes, K. MacKinnon, M. Panger \& S.K. Bearder (eds.). Primates in Perspective: Oxford university press, New York, xvi+720pp.

DiFiore, A., A. Link \& J.L Dew (2008). Diets of Wild Spider Monkeys. pp. 81-137 In: Campbell C.J. (ed.). Spider Monkeys: Behavior, Ecology and Evolution of the Genus Ateles. Cambridge University Press, Cambridge, $\mathrm{x}+420 \mathrm{pp}$

Dunbar, R.I.M. (2002). Modeling primate behavioral ecology. International Journal of Primatology. 23: 785-819

Durham, N.M. (1975). Some ecological, distributional and group behavioural features of Atelinae in southern Peru: with comments on Interspecific relations, pp. 87-102. In: Tuttle, R.T. (ed.). Socioecology and Psychology of Primates. Mouton \& Co, Netherlands. $\mathrm{xi}+474 \mathrm{pp}$

Eisenberg, J.F., M.A. O'connell \& P.V. August (1979). Density, Productivity and distribution of Mammals in Two Venezuelan 
Habitats, pp. 187-207. In: Eisenberg, J.F. (ed.). Vertebrate ecology in the northern neotropics. Smithsonian institution press, Washington DC $271 \mathrm{pp}$.

Estrada, A. (2006). Human and Non-human Primate Co-existence in the Neotropics: a Preliminary View of Some Agricultural Practices as a Complement for Primate Conservation. Ecological and Environmental Anthropology. Online at: http://www.uga.edu/eea/ 02_2006/article04_02_2006.htm.

Estrada, A. \& R. Coates-Estrada (1996). Rain-forest fragmentation and wild populations of primates at Los Tuxtlas, Mexico. International Journal of Primatology 17: 759-783.

Estrada, A., L. Luecke, S. Van Belle, E. Barrueta \& M.R. Meda (2004). Survey of black howler (Alouatta pigra) and spider (Ateles geoffroyi) monkeys in the Mayan sites of Calakmul and Yaxchilan, Mexico and Tikal Guatemala. Primates 45: 33-39.

Estrada, A., L. Lluecke, S. Van Belle, K. French, D. Munoz, Y. Garcia, L. Castellanos \& A. Mendoza (2002). The Black howler monkey (Alouatta pigra) and spider monkey (Ateles geoffroyi) in the Mayan site of yaxchilan, chiapas, Mexico: a preliminary survey. Neotropical Primates 10: 89-95

Flores, O. \& P. Gerez (1988). Conservacion en Mexico: Sintesis sobre Vertebrados Terrestres, Vegetacion y Uso de Suelo. INITEB/ Conservation International. Mexico.

Franklin, I.R. \& R. Frankham (1998). How large must populations be to retain evolutionary potential. Animal Conservation. 1: 69-70.

Freese, C.H., G.L. Heitne, N.R. Castro \& G. Whitesides (1982). Patterns and determinants of monkey densities in Peru and Bolivia, with notes on distributions. International Journal of Primatology 3: 53-90.

Gavilanez-Endara, M.M. (2006). Demografía, Actividad y Preferencia de Hábitat de Tres Especies de Primates (Alouatta palliata, Ateles fusciceps y Cebus capucinus) en un Bosque Nublado del Noroccidente Ecuatoriano. BSc Thesis. Pontificia Universidad Catolica del Ecuador.

Geise, L., L.G. Pereira, D.E.P. Bossi \& H.G. Bergallo (2004). Pattern of elevational distribution and richness of non volant mammals in Itatiaia National Park and its surroundings, in southeastern Brazil. Brazilian Journal of Biology 64: 599-612.

Giannini, N.B. (1999). Selection of diet and elevation by sympatric species of Sturnira in an Andean rainforest. Journal of Mammalogy 80: $1186-1195$

Gillespie, T.R. \& C.A. Chapman (2001). Determinants of group size in the red colobus monkey (Procolobus badius): an evaluation of the generality of the ecological-constraints model. Behavioral Ecology and Sociobiology 50: 329-338.

Gonzalez-Kirchner, J.P. (1999). Habitat use, population density and subgrouping pattern of the Yucatan Spider Monkey (Ateles geoffroyi yucatanensis) in Quintana Roo, Mexico. Folia Primatologica 70: 55-60.

Groves, C. (2001). Primate Taxonomy. Smithsonian Institution Press, Washington, viii+35opp

Henzi, S.P., M.L. Dyson \& A. Deenik (1990). The relationship between altitude and group size in mountain baboons (Papio cynocephalus ursinus). International Journal of Primatology 11: 319-325.

Hines, J.J. (2004) Size and composition of foraging groups of blackhanded spider monkeys (Ateles geoffroyi) in Parque Nacional Pico Bonito, Atlantida, Honduras. American journal of primatology 62(Supp 1): 89

Iwanaga, S. \& S.F. Ferrari (2002). Geographic distribution and abundance of woolly (Lagothrix cana) and spider (Ateles chamek) monkeys in southwestern Brazilian Amazonia. American Journal of Primatology. 56: $57-64$.

IUCN (2009). Ateles In: IUCN 2008. 2008 IUCN Red List of Threatened Species. <www.iucnredlist.org>. Downloaded on 05 June 2009.

Kumara, N.H. \& M. Singh (2004). Distribution and abundance of primates in rainforests of the Western Ghats, Karnataka, India and the conservation of Macaca silenus. International Journal of Primatology 25: $1001-1018$

Lawes, M.J. (1992). Estimates of Population Density and Correlates of the Status of the Samango Monkey Cercopithecus mitis in Natal, South Africa. Biological Conservation. 60: 197-210.

Lenoir, J., J.C. Gegout, P.A. Marquet, P. de Ruffray \& H. Brisse (2008). A significant upward shift in plant species optimum elevation during the 20th century. Science 320: 1768-1771.

Lieberman, D., M. Lieberman, R. Peralta \& G.S. Hartshorn (1996).
Tropical forest structure and composition on large-scale altitudinal gradient in Costa Rica. Journal of Ecology 84: 137-152

Loiselle, B.A. \& J.G. Blake (1991). Temporal variation in birds and fruits along an elevational gradient in Costa Rica. Ecology 70: 180193

Lynch, M. \& R. Lande (1999). The critical effective size for a genetically secure population. Animal Conservation. 1: 70-72

Marshall, A.R., J.E. Topp-Jorgensen, H. Brink \& E. Fanning (2005) Monkey abundance and social structure in two high-elevation forest reserves in the Udzungwa mountains of Tanzania. International Journal of Primatology. 26: 127-145.

McFarland-Symington, M.J. (1986). Ecological determinants of FissionFusion sociality in Ateles and Pan, pp. 181-190. In: Else J.G \& P.C. Lee (eds.). Primate Ecology and Conservation. Cambridge University Press. Cambridge, xii+403pp.

Myers, N., R.A. Mittermeier, C.G. Mittermeier, G.A.B. da Fonseca \& J. Kent (2000). Biodiversity hotspots for conservation priorities. Nature 403: 853-858

Norconk, M.A. \& W.G. Kinzey (1994). Challenge of neotropical frugivory: travel patterns of spider monkeys and bearded sakis. American Journal of Primatology 34: 171-183.

Parry, L. (2004). Large vertebrate communities of primary and secondary forests in the Brazilian Amazon. MSc Dissertation. University of East Anglia.

Peck, M. (2008). Developing a Species and Habitat Action Plan 'Focusing Conservation Efforts for the Brown-headed Spider Monkey (Ateles fusciceps) using Remote Sensing, Predictive Distribution Modeling and Playback Field Survey.' Report to PrimeNet, 36pp.

Peres, C.A. (2000). Effects of subsistence hunting on vertebrate community structure in Amazonian forests. Conservation Biology 14 $240-253$

Pozo R.W.E (2001). Social behavior and diet of the spider monkey, Ateles belzebuth, in the Yasuni national park, Ecuador. Neotropical Primates 9: 74

Primate Specialist Group (2009). The Top 25 most Endangered Primate Species In: IUCN 2009. Primate Specialist group 2009 $<$ www.primate-sg.org $>$. Downloaded on 05 June 2009

Puertas, P. \& R.E. Bodmer (1993). Conservation of a high diversity primate assemblage. Biodiversity and Conservation 2: 586-593.

Ramos-Fernandez, G. \& B. Ayala-Orozoco (2003). Population size and habitat use of spider monkeys at Punta Laguna, Mexico, pp. 191209. In: Marsh, L.K. (ed.). Primates in Fragments. Kluwer Academic/ Plenum, New York, xxiv+428pp.

Salovaara, K., R. Bodmer, M. Recharte \& C. Reyes (2003). Diversity and abundance of mammals. Rapid Biological Inventories 11: 156-164.

Shanee, S. \& M.R. Peck (2008). Elevational changes in a neotropical fig (Ficus spp.) community in North Western Ecuador. iForest. 1: 104106.

Silva-Lopez, G \& J. Jimenez-Huerta (2000). A study of spider monkeys (Ateles geoffroyi vellerosus) in the forest of the crater of santa marta, Veracruz, Mexico. Neotropical Primates 8: 148-150.

Smith, N.D. \& T.J. Killeen (1998). A comparison of the structure and composition of montane and lowland tropical forest in the serranía Pilón Lajas, Beni, Bolivia. In: Dallmeier F. \& J.A. Comiskey (eds.). Forest Biodiversity in North, Central and South America, and the Caribbean. Man and the Biosphere Series. 21: 681-700.

Sorenson, T.C. \& L.M. Fedigan (2000). Distribution of three monkey species along a gradient of regenerating tropical dry forest. Biological Conservation 92: 227-240.

Still, C.J., P.N. Foster \& S.H. Schneider (1999). Simulating the effects of climate change on tropical montane cloud forests. Nature 398: 608-610.

Symington, M.M. (1988). Environmental determinants of population densities in Ateles. Primate Conservation 9: 74-79.

Symington, M.M. (1990). Fission-fusion social organization in Ateles and Pan. International Journal of Primatology 11: 47-61.

Thoisy, B.de., F. Renoux \& C. Julliot (2005). Hunting in Northern French Guiana and its Impact on Primate Communities. Oryx. 39: $149-157$

Tinney, A.W. (2005). Grouping and social behavior of black handed spider monkeys (Ateles geoffroyi) at La Suerte biological field station. American Journal of Primatolgy 66(Supp1): 85-86. 
Tirira, D. (2004). Present status of the brown-headed spider monkey (Ateles fusciceps Gray, 1866) (Primates: Atelidae) in Ecuador. Lyonia 13: 2-9.

van Roosmalen, M.G.M. (1985). Habitat preferences, diet, feeding stratergy and social organization of black spider monkeys (Ateles paniscus paniscus Linnaeus 1758) in Surinam. Acta Amazon 15: 1-238.

Vick, L. \& D. Taub (1995). Ecology and behavior of spider monkeys (Ateles geofroyi) at Punta Laguna, Mexico. American Journal of Primatology 36: 160.

Wallace, R.B (2008). Factors influencing spider monkey habitat use and ranging patterns, pp. 138-154: In Campbell C.J. (ed.). Spider Monkeys: Behavior, Ecology and Evolution of the Genus Ateles Cambridge University Press, Cambridge, $\mathrm{x}+420 \mathrm{pp}$.

Wallace, R.B. (2007). Towing the party line: territoriality, risky boundaries and male group size in spider monkey fission-fusion societies. American Journal of Primatology 69: 1-16.

Wallace, R.B. (2006). Seasonal variations in black-faced black spider monkey (Ateles chamek) habitat use and ranging behavior in a southern Amazonian Tropical Forest. American Journal of Primatology 68: 313-332.

Wallace. R.B., R.L.E. Painter \& A.B. Taber (1998). Primate diversity, habitat preferences, and population density estimates in Noel Kempff Mercado National Park, Santa Cruz Department, Bolivia. American Journal of Primatology 46: 197-211.

White, F. (1986). Census and preliminary observations on the ecology of the black-faced black spider monkey (Ateles paniscus chamek) in Manu National Park, Peru. American Journal of Primatology 11: 125132

Wilson, R.J., D. Guiterrez, J. Guiterrez, D. Martinez, R. Agudo \& V.J. Monserrat (2005). Changes to the elevational limits and extent of species ranges associated with climate change. Ecological Letters 8: 1138-1146.

Wrangham, R.W., J.L. Gittleman \& C.A. Chapman (1993). Constraints on group size in primates and carnivores: population density and day-range as assays of exploitation competition. Behavioural Ecology and Socio-biology 32: 199-209. 